Article

\title{
Remote Distinction of A Noxious Weed (Musk Thistle: Carduus Nutans) Using Airborne Hyperspectral Imagery and the Support Vector Machine Classifier
}

\author{
Mustafa Mirik ${ }^{1}{ }^{*}$, R. James Ansley ${ }^{1}$, Karl Steddom ${ }^{2}$, David C. Jones ${ }^{3}$, Charles M. Rush ${ }^{4}$, \\ Gerald J. Michels, Jr. ${ }^{4}$ and Norman C. Elliott ${ }^{5}$
}

1 Texas A\&M AgriLife Research and Extension Center, 11708 Highway 70 S., Vernon, TX 76385 , USA; E-Mail: jansley@ag.tamu.edu

2 Texas A\&M AgriLife Research and Extension Center, Overton, TX 75684, USA;

E-Mail: kcsteddom@ag.tamu.edu

3 Fort Hood ITAM, DPTMS Range Division, Fort Hood, TX 76544, USA;

E-Mail: dcjones@ag.tamu.edu

4 Texas A\&M AgriLife Research and Extension Center, 6500 Amarillo Blvd. W., Amarillo, TX 79012, USA; E-Mails: crush@ag.tamu.edu (C.M.R.); gmichels@ag.tamu.edu (G.J.M.)

5 USDA-ARS Plant Science Research Laboratory, 1301 N. Western St., Stillwater, OK 74075, USA;

E-Mail: norman.elliott@ars.usda.gov

* Author to whom correspondence should be addressed; E-Mail: mustafamirik@gmail.com; Phone: +1-940-552-9941, Fax: +1-940-552-2317.

Received: 18 November 2012; in revised form: 18 January 2013 / Accepted: 23 January 2013 / Published: 29 January 2013

\begin{abstract}
Remote detection of non-native invasive plant species using geospatial imagery may significantly improve monitoring, planning and management practices by eliminating shortfalls, such as observer bias and accessibility involved in ground-based surveys. The use of remote sensing for accurate mapping invasion extent and pattern offers several advantages, including repeatability, large area coverage, complete instead of sub-sampled assessments and greater cost-effectiveness over ground-based methods. It is critical for locating, early mapping and controlling small infestations before they reach economically prohibitive or ecologically significant levels over larger land areas. This study was designed to explore the ability of hyperspectral imagery for mapping infestation of musk thistle (Carduus nutans) on a native grassland during the preflowering stage in mid-April and during the peak flowering stage in mid-June using the support vector machine classifier and to assess and compare the resulting mapping accuracy for these two
\end{abstract}


distinctive phenological stages. Accuracy assessment revealed that the overall accuracies were $79 \%$ and $91 \%$ for the classified images at preflowering and peak flowering stages, respectively. These results indicate that repeated detection of the infestation extent, as well as infestation severity or intensity, of this noxious weed in a spatial and temporal context is possible using hyperspectral remote sensing imagery.

Keywords: accuracy assessment; invasive plant; weed management; weed infestation; remote sensing; geospatial data

\section{Introduction}

Non-native invasive plant species are well known for their successful exploitation of environmental resources (e.g., water, space, light and nutrients), largely due to their aggressive and competitive ability, prolific seed production and seed longevity [1-3]. Along with having a competitive advantage in resource utilization over native species, many non-native weeds grow in the absence of natural enemies [1,2]. This allows non-native invasive weeds to easily establish and compete with native plants in the environment [2]. Due to these characteristics, non-native invasive weeds usually move from small, manageable infestations to larger areas, reaching levels where control is economically prohibitive [2]. Some non-native invasive species can dominate the vegetative canopy and eventually can form monotypic stands [4,5]. Invasion may alter nutrient accumulation and cycling, hydrology, carbon sequestration and grass production [2,4,6,7]. Weed infestation has been recognized as a primary reason for loss in global biodiversity and even species extinction [8-12]. Therefore, non-native invasive plant species have long been of interest to natural resource managers, ecologists and biological conservationists [13-16].

One non-native weed of major ecological and economic importance in the US, Canada, Australia, New Zealand and southern Africa is musk thistle or nodding thistle (Carduus nutans L.), an aggressive member of the sunflower (Asteraceae) family that is native to North Africa and Eurasia [17-22]. Musk thistle infests a considerable amount of land area in the US (found in 45 states) and Canada (found at least in five provinces) and has a long history in these countries as an invasive species [20,21]. Musk thistle has been declared a noxious weed in many US states, Canadian provinces and Australia. It infests forest, pasture and rangelands, roadsides, railroad rights-of-way, ditch banks, stream beds, waste or disturbed areas, agricultural fields $[17,18,23]$, as well as residential areas. The presence of this weed can impede grazing by livestock and decreases the forage production due to competition with grasses [17,18]. Since livestock do not graze musk thistle, it easily outcompetes grassland forage species and can dominate entire fields with up to 150,000 plants per hectare [1,22]. It has been determined that a single musk thistle per $1.5-\mathrm{m}^{2}$ reduces pasture yields by $23 \%$ [24].

Early determination of the distribution and severity of rapidly spreading invasive populations of musk thistle is needed to implement mitigation treatments, but accurate assessments are often difficult or impossible to obtain with ground surveys, because of the extensive land area involved, time and labor required and inaccessibility of many areas [25-27]. Therefore, remote sensing has received considerable attention as a rapid, inexpensive and non-destructive method for assessing non-native 
noxious species invasions [6,27]. It is a technology that provides a complete assessment instead of an assumed level based on traditional field-based sub-sampling methods.

A wide range of sensor systems, including aerial photographs, airborne and satellite multispectral and hyperspectral images have been successfully utilized for mapping the distribution of certain species [28-36]. A large number of investigators [37-42] have discussed the superiority of hyperspectral imaging sensors (also known imaging spectrometry), such as Airborne Imaging Spectroradiometer for Applications (AISA; Specim Inc., Oulu, Finland) over multispectral instruments, such as the Landsat Thematic Mapper. The former systems collect spectral information in continuous, narrow spectral channels, while the latter ones record spectral reflectance at a few wide, non-continuous wavelengths separated by spectral segments where no measurements are taken. The hyperspectral system was designed to separate the surface optical properties into tens of bands with spectral resolution less than $20 \mathrm{~nm}$ or smaller through the visible, near infrared (NIR) and mid-infrared regions of the electromagnetic spectrum $(400-2,500 \mathrm{~nm})$. These narrow and continuous bands provide ample spectral information to identify and distinguish between spectrally similar, but unique, surface materials $[39,43,44]$. Consequently, hyperspectral imagery provides the potential for more detailed and accurate spectral information than multispectral images. Hyperspectral data have been applied to a wide range of spatial modeling and vegetation mapping, including detecting crop stress and classifying non-native invasive plants at the species level across a range of community and ecosystem types [41]. Hyperspectral sensors can capture reflectance features of chemical compounds in plants, including lignin, cellulose, nitrogen, chlorophyll, carotenoids and water [6,45-47]. Another important characteristic of remotely sensed imagery for mapping plant species is the spatial resolution or pixel size representing the smallest area identifiable in the imagery. Higher spatial resolution imagery often contains detailed intraspecies spectral variability than lower resolution imagery, when target species occur in small patches or cover smaller areas than the pixel size $[28,48,49]$. Timing, location, species composition, spectral and spatial resolutions are all important for vegetation mapping at the species level, because spectral reflectance from vegetation is determined by structural and biochemical properties, including leaf area, leaf angle distribution, architecture, biochemical and pigment (lignin, cellulose, chlorophylls, carotenes, nitrogen and water) contents [46,47] over time and space.

The literature indicates that there is a growing body of work on the hyperspectral mapping of non-native invasive species [50-57]. Most of the previous hyperspectral remote sensing studies dealing with mapping invasive plants have commonly utilized Airborne Visible Infrared Imaging Spectrometer, HyMap and Compact Airborne Spectrographic Imager images with spectral resolution $\geq 10 \mathrm{~nm}$ and spatial resolution $\geq 1.5 \mathrm{~m}$. In addition to this, spectral angle mapper and mixture tuned matched filtering were commonly employed as the classification algorithms after dimension reduction or transformation of hyperspectral data, such as principal component analysis, minimum noise fraction or vegetation indices. Some of the non-native invasive species frequently distinguished and mapped in the USA include saltcedar (Tamarix spp.) [33,52,58,59], leafy spurge (Euphorbia esula L.) [51,56,57], spotted knapweed (Centaurea maculosa Sam.) [32,48,53] and yellow starthistle (Centaurea solstitialis) [50,54,55]. Recently, a mixture of Canada thistle (Cirsium arvense L. Scop.) and musk thistle infestation in a Nebraska floodplain was mapped using AISA hyperspectral imagery [33].

Despite the use of hyperspectral data for identification and mapping of non-native invasive plants and the large distribution of musk thistle in the US and other countries, the application of very narrow 
banded (very high spectral resolution) and high spatial resolution hyperspectral imagery for mapping musk thistle on grasslands and rangelands is not well studied. Utilizing very narrow banded and high spatial resolution hyperspectral data to discriminate and separate invasive musk thistle from highly variable rangeland vegetation comprised of many species of grasses and broadleaved forbs is needed in order to improve monitoring population dynamics and developing long-term adaptive management practices for musk thistle. Typically, in the southern Great Plains (in Texas and Oklahoma, USA), the diversity of rangeland species at any one site includes species with cool-season $\left(\mathrm{C}_{3}\right)$ or warm-season $\left(\mathrm{C}_{4}\right)$ photosynthetic pathways that usually have very different periods of physiological activity during the growing season and would have markedly different spectral properties at any one point in time.

Our primary objective was to evaluate the use of very narrow banded (average about $2.25 \mathrm{~nm}$ in the visible, $3.5 \mathrm{~nm}$ in the NIR regions and $2.9 \mathrm{~nm}$ in the visible and NIR wavelengths; Table 1) and 1-m spatial resolution hyperspectral data and the support vector machine (SVM) classification method for detecting and discriminating musk thistle from the co-occurring vegetation in a rangeland pasture. The secondary objectives of our study were to (1) examine the spectral properties of musk thistle and surrounding vegetative land cover classes for species discrimination, (2) explore the ability of aerial hyperspectral imagery for detecting and mapping musk thistle infestations at the preflowering stage in mid-April and the peak flowering stage in mid-June and (3) compare the mapping accuracy for these two distinctive phenological growth patterns. Our study presents a new application of hyperspectral data in terms of relative value of seasonal images for management applications, spatial and spectral resolutions of hyperspectral data and classification method presented. We initiated this study to fill an important gap in the application of hyperspectral imagery for detecting an invasive plant at the species level. Since the hyperspectral remote detection of musk thistle has not been well documented for preflowering and full flowering phenological stages, our study presents the first application of hyperspectral data for discriminating musk thistle at two distinct growth stages.

Table 1. Waveband characteristics of Airborne Imaging Spectrometer for Applications (AISA) used to acquire hyperspectral imagery of a musk thistle infestation in grassland near the city of Friona, TX, USA in 2006.

\begin{tabular}{cccccc}
\hline Band & CW & BW & Band & CW & BW \\
\hline 1 & 509 & 8.6 & 26 & 711 & 0.7 \\
2 & 536 & 3.8 & 27 & 716 & 0.7 \\
3 & 540 & 3.8 & 28 & 722 & 0.7 \\
4 & 545 & 3.8 & 29 & 725 & 0.7 \\
5 & 550 & 3.8 & 30 & 730 & 0.7 \\
6 & 555 & 3.8 & 31 & 735 & 0.7 \\
7 & 559 & 3.8 & 32 & 741 & 0.7 \\
8 & 564 & 3.8 & 33 & 746 & 0.7 \\
9 & 569 & 3.8 & 34 & 753 & 4.2 \\
10 & 582 & 3.8 & 35 & 758 & 4.2 \\
11 & 591 & 0.7 & 36 & 763 & 4.2 \\
\hline
\end{tabular}


Table 1. Cont.

\begin{tabular}{cccccc}
\hline Band & CW & BW & Band & CW & BW \\
\hline 12 & 601 & 0.7 & 37 & 768 & 4.2 \\
13 & 611 & 0.7 & 38 & 774 & 4.2 \\
14 & 621 & 0.7 & 39 & 779 & 4.2 \\
15 & 631 & 0.7 & 40 & 784 & 4.2 \\
16 & 642 & 0.7 & 41 & 789 & 4.2 \\
17 & 650 & 0.7 & 42 & 794 & 4.2 \\
18 & 660 & 0.7 & 43 & 800 & 4.2 \\
19 & 666 & 0.7 & 44 & 805 & 4.2 \\
20 & 671 & 0.7 & 45 & 812 & 4.2 \\
21 & 676 & 0.7 & 46 & 822 & 4.2 \\
22 & 681 & 0.7 & 47 & 834 & 7.7 \\
23 & 691 & 0.7 & 48 & 845 & 7.7 \\
24 & 701 & 0.7 & 49 & 864 & 7.7 \\
25 & 706 & 0.7 & 50 & 885 & 9.4 \\
\hline
\end{tabular}

CW: Center wavelength (nm); BW: Band width (nm).

\section{Materials and Methods}

\subsection{Site Description}

A musk thistle infestation was identified on a grassland site near the city of Friona in Parmer County located about $114 \mathrm{~km}$ south west of Amarillo, Texas, USA $\left(34^{\circ} 38^{\prime} 2.85^{\prime \prime} \mathrm{N}, 102^{\circ} 48^{\prime} 4.18^{\prime \prime} \mathrm{W}\right.$ and elevation approximately 1,211 m) in early June 2003 (Figure 1) and monitored thereafter until mid-summer 2006. Musk thistle was sprayed in 2004 and mowed by the landowner in 2005 (personal observation); however, the infestation rebounded in 2006. Image collection flights were conducted over the study area when the musk thistle was at preflowering stage on 14 April and at peak flowering stage on 15 June 2006. Herbaceous plants found at the site consisted of $\mathrm{C}_{3}$ (cool-season) grasses-needle and threads (Stipa spp.) and bromegrasses (Bromus spp.) - $\mathrm{C}_{4}$ (warm-season) grasses-Johnsongrass (Sorghum halepense L.) and purple three-awns (Aristida spp.) - and broad-leaf forbs-Russian thistle (Salsola iberica L.) and tansy mustard (Descurainia spp.). In addition, a field planted to wheat (Triticum aestivum L.) occupied a small portion of the image in April. Russian thistle, Johnsongrass and brome are non-native invasive species, while tansy mustard is native, but can be invasive. Needle and thread and purple threeawn are native; needle and threads are considered desirable rangeland forage grasses, whereas purple threeawn is not and is an indicator of overgrazing. None of these species were planted by humans, with the exception of wheat. Actively growing and fully green plants in April were tansy mustard, brome, wheat and musk thistle. In June, actively growing species were musk thistle, Johnsongrass and Russian thistle, because cool-season tansy mustard, brome grass and wheat had senesced by mid-June. 
Figure 1. Location of study site in Parmer County (a) in TX (b), USA.

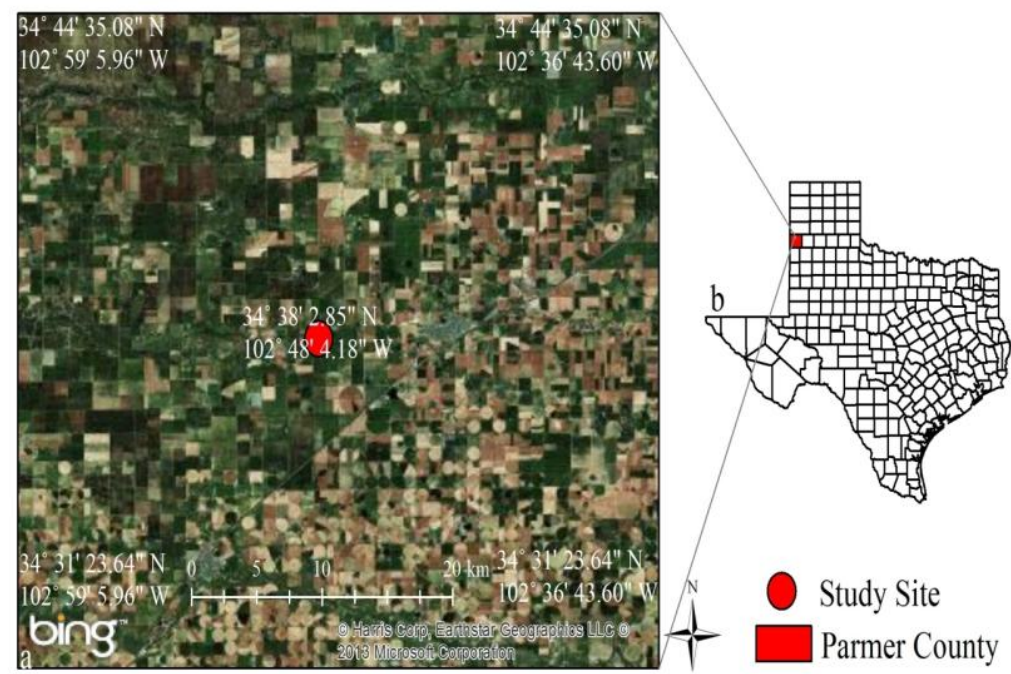

\subsection{Imagery Acquisition}

An Airborne Imaging Spectrometer for Applications mounted in a Cessna 172 airplane was used to acquire the images. The AISA is a hyperspectral pushbroom type airborne imaging spectrometer. It had a spectral range from 505 to $900 \mathrm{~nm}$ with bands as small as $0.7 \mathrm{~nm}$ and as large as $9.4 \mathrm{~nm}$. Under typical conditions in a Cessna 172 airplane, the AISA can acquire between 20 and 60 bands at a spatial resolution between 1-m and 4-m per pixel. It captured 384 pixels across track with a $22.7^{\circ}$ field of view. Resolution along the track for a single image was limited by a disk space of two gigabytes. Downwelling irradiance was measured simultaneously via a fiber optic sensor mounted on the roof of the airplane. The downwelling irradiance was used to calibrate the image. Navigation data for georectification were collected by an onboard Boeing C-MIGITS II integrated Inertial Navigation System/Global Positioning System (INS/GPS; Systron Donner Inertial Division, Concord, CA, USA). Radiometric and geometric corrections were done using Caligeo image preprocessing software version 1.7 (Specim Inc., Oulu, Finland) using sensor specific calibration data. The images were atmospherically calibrated using Fast Line-of-sight Atmospheric Analysis of Spectral Hypercubes (FLAASH) in Environment for Visualizing Images software (ENVI; Exelis Visual Information Solutions, Boulder, CO, USA). Using this atmospheric calibration method, radiance-at-sensor was converted to apparent surface reflectance. Spatial resolution of the image collected over the research site was $1-\mathrm{m}$ by $1-\mathrm{m}$ with a flight height of about $1,000-\mathrm{m}$, and there were 50 bands ranging from $509 \mathrm{~nm}$ to $885 \mathrm{~nm}$ (Table 1).

\subsection{Imagery Classification}

The 1-m image allowed clear and visual identification of musk thistle and other vegetation based on the spectral contrast among vegetation and senescent grasses or bare ground to extract training samples for classification. Therefore, training samples manually extracted from the imagery, consisted of 5-10 polygons, each of which had 5-20 pixels from the canopy or each land cover type with 75\% canopy cover at locations easily identified on the ground and on the image (Table 2). Training samples were also used to obtain the spectral profile of plant species and bare ground (Figure 2). 
Table 2. Summary of training samples used to extract spectral signatures and classify land cover classes in images taken over the study site near the city of Friona, TX, USA in April and June 2006.

\begin{tabular}{ccc}
\hline Classes in April & Number of Pixels/per Polygon & Total Polygon \\
\hline Musk thistle & 20 & 10 \\
Tansy mustard & 13 & 7 \\
Brome grass & 6 & 5 \\
Senescent grass & 5 & 7 \\
Wheat & 20 & 10 \\
Bare ground & 20 & 10 \\
\hline Classes in June & & \\
\hline Musk thistle & 20 & 10 \\
Johnsongrass & 14 & 6 \\
Russian thistle & 9 & 8 \\
Senescent grass & 5 & 7 \\
Bare ground & 20 & 10 \\
\hline
\end{tabular}

Figure 2. Spectral profile of training samples for musk thistle $(\mathrm{N}=200)$, tansy mustard $(\mathrm{N}=91)$, brome grass $(\mathrm{N}=30)$, wheat $(\mathrm{N}=200)$, senescent grass $(\mathrm{N}=35)$ and bare ground $(\mathrm{N}=200)$ in April (a) and musk thistle $(\mathrm{N}=200)$, Russian thistle $(\mathrm{N}=72)$, Johnsongrass $(N=84)$, senescent grass $(N=35)$ and bare ground $(N=200)$ in June $(b) 2006$.

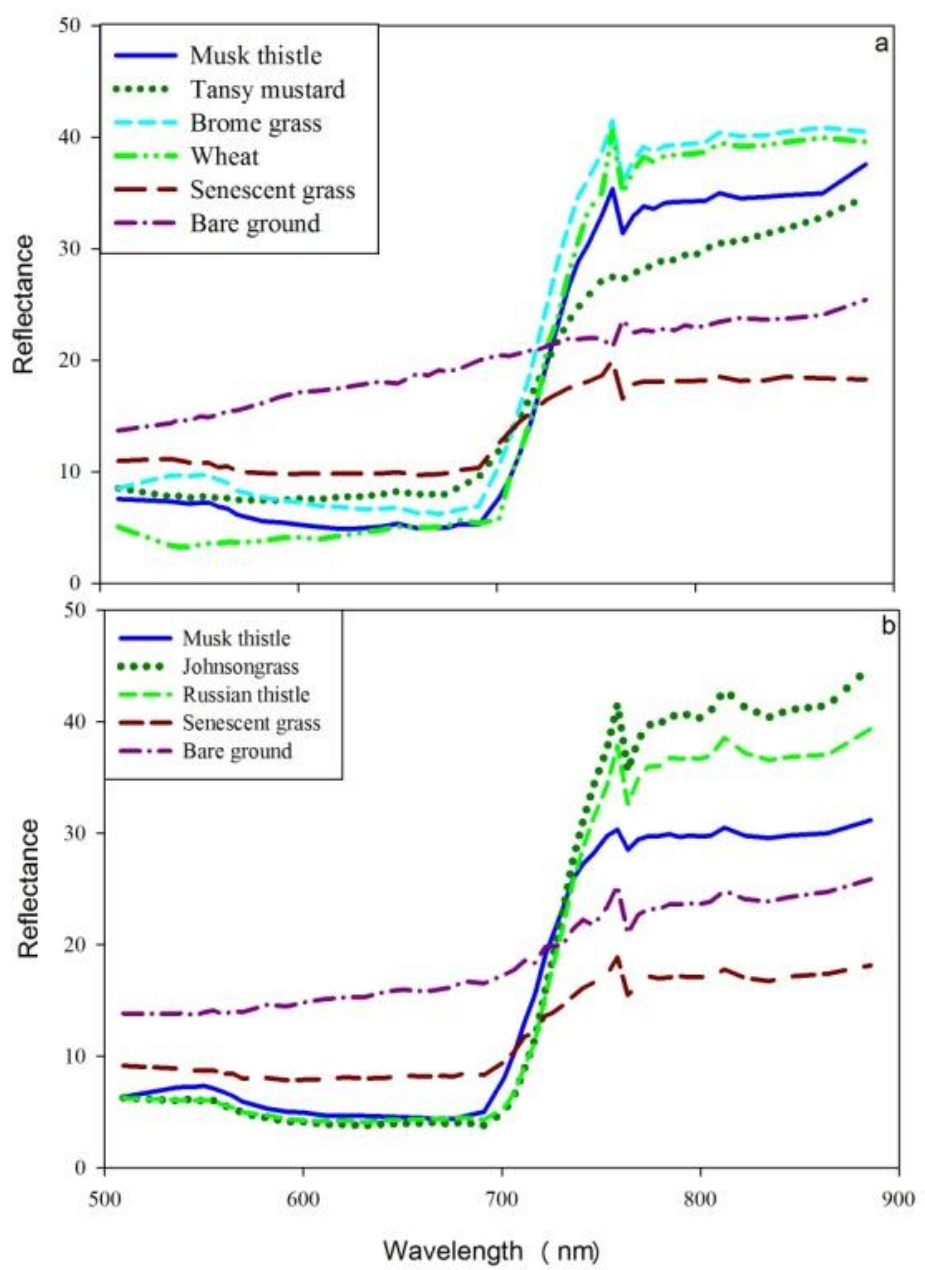


Before performing classification, the spectral profile of image components for plant species was examined (Figure 2). The spectral profile of each species was the mean values of training samples. Spectral reflectance for plant species in the visible and NIR regions were tested for statistical significance using paired $t$-tests assuming unequal variance at $\alpha=0.05$ for all data pairs using Microsoft Excel. The largest significant difference appeared in the NIR; therefore, the last 15 bands (bands 36-50; 764-885 $\mathrm{nm}$ ) in this region formed a spectral subset for image classification.

Image classification was performed using the SVM in ENVI. The SVM is a supervised machine learning method that performs classification based on the statistical learning theory. The SVM classifies data by separating a hyperplane that provides the best separation between classes in a multidimensional feature space. This hyperplane is the decision surface on which the optimal class separation takes place. The optimal hyperplane is the one that maximizes the distance between the hyperplane and the nearest positive and negative training example called the margin. From a given set of training samples, the optimization problem is solved to find the hyperplane that leads to a sparse solution. Although the SVM is a binary classifier in its simplest form, implementation of the SVM classifier in ENVI was extended to more than two classes by splitting the problem into a series of binary class separations (ENVI User's Guide).

In order to represent more complex shapes than linear hyperplanes, a variety of kernels, including the polynomial, the radial basis function and the sigmoid, can be used for performing SVM classification in ENVI. The SVM was employed using the radial basis function kernel for performing the pairwise classification. There is also a penalty parameter that can be introduced to the SVM classifier to allow for misclassification during the training process. The penalty parameter was set to its maximum value, whereas a classification probability threshold of zero was used in order to classify all pixels (ENVI User's Guide).

The image taken in April was classified for bare ground, senescent grass, musk thistle, tansy mustard, brome grass and wheat. Since our target species was musk thistle, bare ground and senescent grass classes were combined into a group and reported as non-vegetation, while tansy mustard, brome grass and wheat classes were combined into another group and reported as other vegetation using post classification procedure in ENVI for April image classification. Combining classes resulted in a three-category (musk thistle, other vegetation and non-vegetation) final map of the study site. The same classification and procedure for combining classes were applied to the June image, except for the other vegetation category that included Johnsongrass and Russian thistle (Figure 3).

Figure 3. Color infrared hyperspectral imagery acquired in June 15, 2006 (a), classified image (b) and views of musk thistle infestation (c,d) at the study site. The entire area is native grassland, with the exception of a wheat field on the far right, right of the main road.

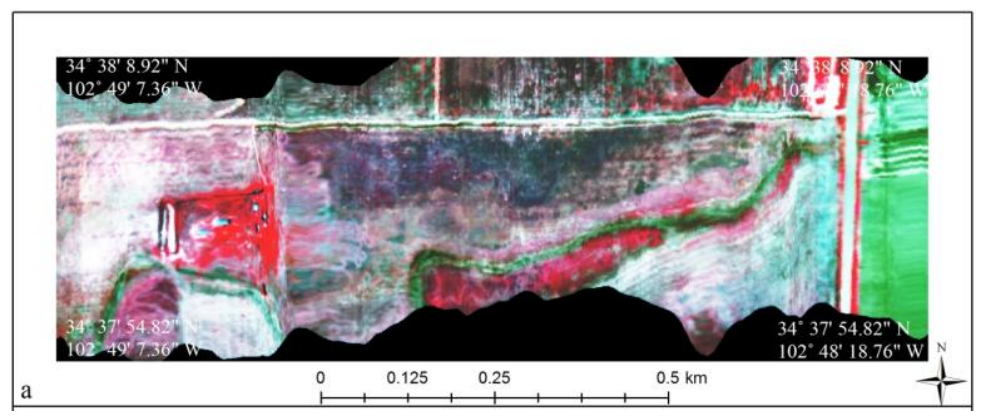


Figure 3. Cont.

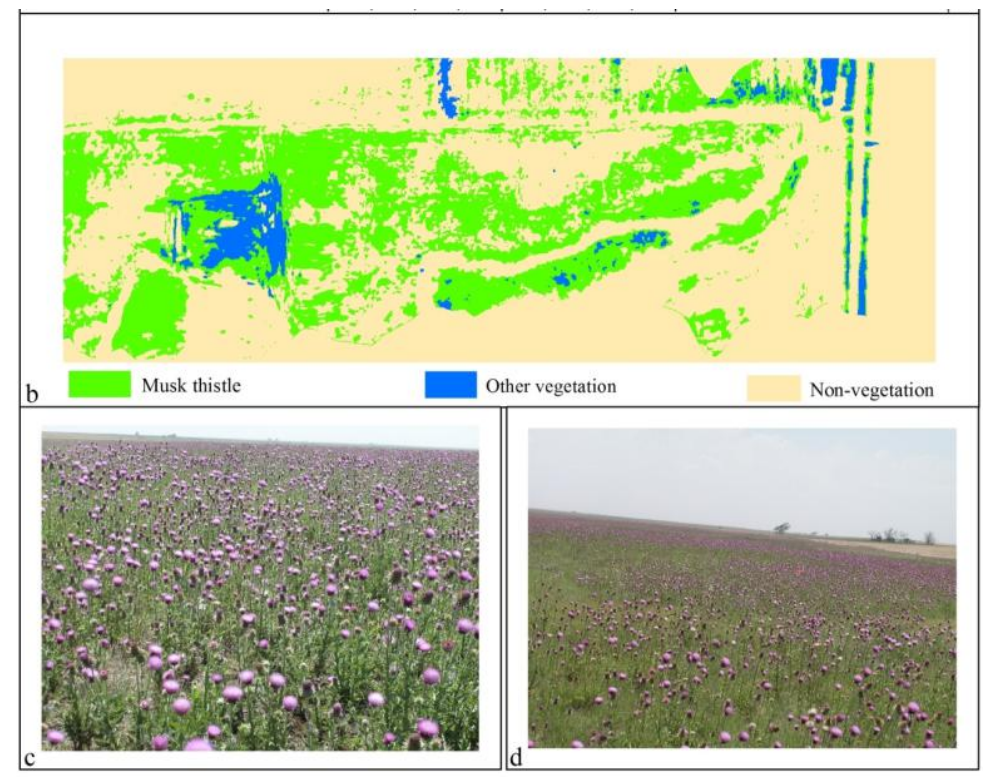

\subsection{Accuracy Assessment}

Classification of remotely sensed imagery is the process of assigning variables into discrete categories of useful information. However, errors of classification occur because of mixed pixels, similar spectra of different materials, positional errors and human errors [60]. The most effective way to represent classification accuracy is via an error matrix [61-64]. Therefore, accuracy assessment for classification was made by constructing an error matrix for each classified image. An error matrix is a square, with the number of columns and rows being equal to the numbers of categories whose classification accuracy is being evaluated [61-64]. Error matrices for each classification map were generated by comparing the classified classes with the ground verification data. Error matrices to evaluate the classification accuracy were calculated, including overall, user's and producer's accuracies.

There is no single set standard for selection of the image and ground areas for comparison [61-63,65]. Because a pixel in an image has an arbitrary location on the ground and because positional errors of maps and global positioning system receivers become significant with small pixel sizes, areas based on geographic information system polygons are used frequently [63]. However, using individual pixels is appropriate if a per-pixel classification is assessed for accuracy, which avoids problems caused by generating "homogeneous" polygons on a landscape [66,67]. It has been shown that pixel positional error results in a conservative bias of the accuracy assessment [68]; therefore, the unavoidable positional error introduced into this assessment would result in lower or conservative estimates of mapping accuracy $[60,69,70]$.

\subsection{Field Validation}

Field validation (accuracy assessment) of the classification performance was carried out using verification data (ground control points) at the site. Verification data containing 330 locations (points) with an equal spacing were created using the Farm Works software package (CTN Data Service, Hamilton, IN, USA). The verification points were exported to a field computer equipped with Farm 
Works software and a global positioning system receiver and navigated on the ground on the same dates when images were acquired at the site. At each verification point within a 1-m radius area, presence (at least one musk thistle plant found) and absence (no musk thistle plant found) of musk thistle were recorded. This ground data collection prior to image processing created an unbiased field validation. Of the 330 points, only 208 and 270 points fell within April and June images, respectively. Therefore, only those verification points were used for accuracy assessment. Subsequent to image classification, those points were overlaid on a land cover map, where one-to-one matching was performed to contract an error matrix for each date. Training samples were not included in the validation dataset.

\section{Results}

The mean reflectance spectra of training samples extracted from the hyperspectral imagery acquired for musk thistle and associated vegetation in April and June are shown in Figure 2. Paired $t$-test comparisons of mean reflectance spectra of training samples for the same land cover types are presented in Table 3. In April, musk thistle reflected significantly less light in the green region (510-592 nm) than tansy mustard, brome grass, senescent grass and bare ground (Figure 2(a)). In the same region, musk thistle had significantly more reflectance than wheat. Brome grass had significantly higher reflectance than musk thistle, tansy mustard and wheat and significantly less reflectance than senescent grass and bare ground in this wavelength region. The reflectance spectra of the training samples in the red region of the spectrum exhibited similar reflectance patterns to the green portion of the spectrum. In the 600-691 nm wavelength range, all compared pairs were significantly different, with one exception: that the comparison of musk thistle and wheat was insignificant (Table 3). Around $675 \mathrm{~nm}$, reflectance from senescent grass, brome grass, tansy mustard, musk thistle and wheat started to increase. In the 701-758 nm wavelength range, all pairs of training samples for land cover classes were insignificant, with the exceptions of tansy mustard vs. senescent grass, brome grass $v s$. senescent grass and senescent grass $v s$. bare ground that were significant. In the NIR region $(763-885 \mathrm{~nm})$, musk thistle had significantly less reflectance than both wheat and brome grass, while it had significantly more reflectance than senescent grass, bare ground and tansy mustard (Figure 2(a) and Table 3). There was no significant difference between brome grass and wheat in the $763-885 \mathrm{~nm}$ wavelengths, whereas all other pairs were significant. Reflectance from bare ground gradually increased in the visible and NIR regions examined.

In June, musk thistle reflected significantly more light than Russian thistle and Johnsongrass, whereas it had significantly less reflectance than both senescent grass and bare ground in the 510-592 nm regions (Figure 2(b) and Table 3). There was no difference between Johnsongrass and Russian thistle, while all other pairs were significant in the green portion of the spectrum. In the red region $(600-691 \mathrm{~nm})$, reflectance from musk thistle was insignificant when compared to those of Johnsongrass and Russian thistle. In this part of the spectrum, the remaining pairs showed significant difference. Around $690 \mathrm{~nm}$, reflectance from senescent grass, musk thistle, Russian thistle and Johnsongrass started to increase. From $701 \mathrm{~nm}$ to $758 \mathrm{~nm}$, reflectance between musk thistle and senescent grass, Johnsongrass and senescent grass and senescent grass and bare ground was significant, while all remaining pairs were insignificant. Musk thistle had significantly lower reflectance than Johnsongrass and Russian thistle, whereas it had significantly higher reflectance than bare ground and senescent grass in the $763-885 \mathrm{~nm}$ 
range. Reflectance from bare ground steadily increased in the full spectrum studied. In both dates, reflectance of senescent grass was significantly lower than bare ground in the visible and NIR spectrums.

Table 3. Paired $t$-test comparison of the mean reflectance spectra of training samples for land cover classes. The training samples were manually extracted from April and June images over the visible and near infrared (510-885 nm) wavelengths.

\begin{tabular}{|c|c|c|c|c|c|c|c|c|}
\hline \multirow{3}{*}{ Spectral Pair in April } & \multicolumn{8}{|c|}{ Wavelength Range (nm) } \\
\hline & \multicolumn{2}{|c|}{$510-592$} & \multicolumn{2}{|c|}{$600-691$} & \multicolumn{2}{|c|}{$701-758$} & \multicolumn{2}{|c|}{$763-885$} \\
\hline & $t$ & $p$ & $t$ & $p$ & $t$ & $p$ & $t$ & $p$ \\
\hline Musk thistle $v s$. tansy mustard & 2.16 & $<0.00$ & 2.09 & & 2.12 & 0.64 & 2.06 & \\
\hline Musk Thistle $v s$. brome grass & 2.08 & $<0.00$ & 2.08 & $<0.00$ & 2.09 & 0.21 & 2.04 & $<0.00$ \\
\hline & 2.10 & $<0.00$ & 2.09 & 0.15 & 2.09 & 0.73 & 2.05 & \\
\hline Musk thistle $v s$. senescent grass & 2.11 & $<0.00$ & 2.06 & $<0.00$ & 2.20 & 0.06 & 2.11 & $<0.00$ \\
\hline Musk thistle $v s$. bare ground & 2.07 & $<0.00$ & 2.07 & $<0.00$ & 2.23 & 0.63 & 2.07 & $<0.00$ \\
\hline Tansy mustard $v$ & 2.18 & $<0.00$ & 2.06 & $<0.00$ & 2.13 & 0.06 & 2.07 & $<0.00$ \\
\hline & 2.12 & $<0.00$ & 2.10 & $<0.00$ & 2.14 & 0.42 & 2.07 & $<0.00$ \\
\hline Tansy mustard & 2.11 & & 2.09 & & 2.16 & 02 & 2.13 & \\
\hline Tansy mustard $v s$. bare ground & 2.18 & $<0.00$ & 2.06 & $<0.00$ & 2.23 & 0.94 & 2.10 & $<0.00$ \\
\hline Brome grass vs. wheat & 2.12 & $<0.00$ & 2.10 & $<0.00$ & 2.09 & 0.39 & 2.05 & 0.06 \\
\hline Brome grass $v s$ & 2.12 & $<0.00$ & 2.08 & $<0.00$ & 2.20 & $<0.00$ & 2.10 & $<0.00$ \\
\hline & & & & & & & 2.07 & \\
\hline Wheat $v s$. senescent grass & 2.08 & $<0.00$ & 2.07 & $<0.00$ & 2.2 & 0.04 & 2.10 & $<0.00$ \\
\hline Wheat & 2.12 & $<0.00$ & 2.09 & $<0.00$ & 2.23 & 0.39 & 2.07 & $<0.00$ \\
\hline Senescent grass $v s$. bare ground & 2.12 & $<0.00$ & 2.07 & $<0.00$ & 2.17 & $<0.00$ & 2.07 & $<0.00$ \\
\hline \multicolumn{9}{|l|}{ Spectral Pair in June } \\
\hline & 2.09 & $<0.00$ & 2.15 & $=0.01$ & 2.12 & 0.78 & 2.12 & $<0.00$ \\
\hline Musk thistle $v$ & 2.09 & $<0.00$ & 2.14 & $=0.11$ & 2.11 & 0.92 & 2.10 & $<0.00$ \\
\hline Musk thistle & 2.11 & $<0.00$ & 2.12 & $<0.00$ & 2.16 & $<0.00$ & 2.05 & $<0.00$ \\
\hline Musk thistle $v s$. & 2.16 & $<0.00$ & 2.07 & $<0.00$ & 2.18 & 0.55 & 2.08 & $<0.00$ \\
\hline Johnsongrass $v s$. Russian thistle & 2.09 & 0.86 & 2.06 & $<0.00$ & 2.09 & 0.75 & 2.06 & $<0.00$ \\
\hline Johnsongrass $v s$. senescent grass & 2.12 & $<0.00$ & 2.07 & $<0.00$ & 2.20 & 0.04 & 2.12 & $<0.00$ \\
\hline Johnsongrass $v s$. bare ground & 2.16 & $<0.00$ & 2.11 & $<0.00$ & 2.20 & 0.51 & 2.08 & $<0.00$ \\
\hline Russian thistle $v s$. senescent grass & 2.11 & $<0.00$ & 2.07 & $<0.00$ & 2.02 & 0.05 & 2.10 & $<0.00$ \\
\hline Russian thistle $v s$. bare ground & 2.14 & $<0.00$ & 2.11 & $<0.00$ & 2.20 & 0.77 & 2.06 & $<0.00$ \\
\hline Senescent grass $v s$. bare ground & 2.10 & $<0.00$ & 2.09 & $<0.00$ & 2.09 & $<0.00$ & 2.07 & $<0.00$ \\
\hline
\end{tabular}

The classification map in June for musk thistle, other vegetation and non-vegetation is illustrated in Figure 3. The error matrices that compared ground verification data with classified data in April and in June 2006 are contained in Table 4. An overall mapping accuracy of 79\% in April and 91\% in June was achieved for musk thistle detection. About $28 \%$ of the other land cover types were included into musk thistle category, whereas about $21 \%$ of the musk thistle were misclassified as other classes by the classification method performed in April. In June, approximately $12 \%$ of the musk thistle were excluded from the musk thistle class, while about $10 \%$ of other cover types were included in the musk thistle category. 
Table 4. Confusion matrices (top for April and bottom for June image classifications) generated from the ground verification and classified data for musk thistle, other vegetation and non-vegetation components.

\begin{tabular}{|c|c|c|c|c|}
\hline April & Actual Category & & & \\
\hline Classified Category & Present & Absent & Row Total & User's Accuracy (\%) \\
\hline Present & 66 & 26 & 92 & 71.74 \\
\hline Absent & 18 & 98 & 116 & 84.48 \\
\hline Column total & 84 & 124 & 208 & \\
\hline Producer's accuracy (\%) & 78.57 & 79.03 & & \\
\hline Overall accuracy $(\%)$ & 78.85 & & & \\
\hline June & Actual Category & & & \\
\hline Classified Category & Present & Absent & Row Total & User's Accuracy (\%) \\
\hline Present & 95 & 11 & 106 & 89.62 \\
\hline Absent & 13 & 151 & 164 & 92.07 \\
\hline Column total & 108 & 162 & 270 & \\
\hline Producer's accuracy (\%) & 87.96 & 93.21 & & \\
\hline Overall accuracy (\%) & 91.11 & & & \\
\hline
\end{tabular}

\section{Discussion}

All physiologically active vegetation had lower reflectance in the visible region until around 706-730 $\mathrm{nm}$ and higher reflectance in the NIR beyond $730 \mathrm{~nm}$ when compared to senescent grass and bare ground. The visible region is defined as pigment-related absorption wavelengths that are primarily governed by the presence of chlorophylls $a$ and $b$ and carotenoids [28,29,71]. This indicates that actively growing musk thistle, tansy mustard, brome grass, wheat, Johnsongrass and Russian thistle had higher chlorophylls and carotenoids than senescent grass. Musk thistle reflected more light than wheat and less light than tansy mustard and brome grass in the visible spectrum in April. This indicates that musk thistle had a higher amount of photosynthetic pigments than both tansy mustard and brome grass, but it had a lower amount of pigments than wheat during this early spring date, when wheat in this region was physiologically very active.

In June, musk thistle had a lower amount of photosynthetic pigments than Johnsongrass and Russian thistle. The NIR reflectance from vegetation increases with the increasing green leaf or canopy density and with decreasing gaps between them due to the internal scattering at the cell wall-air interfaces within the leaf [72]. In both April and June, musk thistle had lower reflectance than wheat, brome grass, Johnsongrass and Russian thistle and higher reflectance than tansy mustard and senescent grass in the 763-885 nm wavelengths. This implies that musk thistle had lower leaf or canopy density when compared to wheat, brome grass, Johnsongrass and Russian thistle and higher leaf or canopy density than senescent grass and tansy mustard.

A similar observation to our study was made that flowering shoots of leafy spurge had higher reflectance in the visible region of the spectrum compared to co-occurring vegetation [60]. However, these authors also found higher reflectance from leafy spurge in the NIR spectrum than that from other vegetation. In our study, musk thistle had lower reflectance, starting approximately around $720-740 \mathrm{~nm}$, and stayed lower in the remaining NIR portion of the spectrum examined. Higher NIR reflectance from flowering leafy spurge may be an effect of sample collection from areas with high density of leafy 
spurge [60]. Spectral reflectance of musk thistle in our study also closely agreed with the results previously reported for flowering yellow starthistle [30,55] and perennial pepperweed (Lepidium latifolium) [73]. The peak flowering stage of these species was the best time to spectrally identify and differentiate them from background vegetation. Thus, acquiring very narrow banded hyperspectral imagery during the peak flowering of musk thistle could allow in detail identification of this noxious weed from the background vegetation.

There is no set standard for classification accuracy as to what level of accuracy is adequate. The acceptable level of mapping accuracy depends on the project-based choice that differs based on the needs of the end users and utilization of the classification results $[60,62]$. An accuracy target of $85 \%$ was recommended by [74], and an overall accuracy target of $85 \%$ with no individual class accuracy $<70 \%$ was suggested by [75]. Although there is no information related to the acceptable classification accuracies specified for remote detection of musk thistle, a threshold of the user's accuracy $>70 \%$ is required for mapping leafy spurge [51]. Based on these recommended accuracy guidelines, our classification of the April image did not meet the overall map accuracy target of 85\%, but provided the recommended levels of the user's and producer's accuracies. Results from the June classification indicated that the overall, producer's and user's accuracies were above recommended guidelines. We achieved these high accuracies because we used a suitable classification algorithm, a very narrow banded hyperspectral imagery with 1-m spatial resolution, a spectral range where separability largely occurred and the ground verification method extended to the entire study area for musk thistle infestation. One of the most likely utilizations of these accuracy maps would be to track changes in musk thistle population density over time and space. With consistent and repeatable classification methodology, the level of accuracies we accomplished in this study would present very accurate musk thistle distribution over the study site.

Image classification methods for weed identification and mapping have a tendency to overestimate the target species [48]. In our study, the producer's accuracy of $88 \%$ was slightly lesser than the user's accuracy of $90 \%$ for the June image classification. Producer's accuracy is more important than user's accuracy for weed detection, because undetected or omission of target weeds (false negative) is the factor that most likely hampers control efforts [73]. There is greater potential for misclassification of musk thistle when it grows in close proximity to dense patches of background live vegetation, in locations where musk thistle with canopy coverage is $<15 \%$ or when individual musk thistle plants are small in size. All of these factors affected classification accuracy in the present study. Our classification results were consistent with the findings of other studies. For example, hoary cress (Cardaria draba) with 30\% cover [76], leafy spurge with cover as low as 10\% [51] and spotted knapweed (Centaurea maculosa) with only $1 \%$ cover [53] were successfully detected using hyperspectral images with pixel sizes of 3 by $3-\mathrm{m}, 3.5$ by $3.5-\mathrm{m}$ and 5 by $5-\mathrm{m}$, respectively.

Accuracy assessment performed for April and June image classifications resulted in a higher mapping accuracy in June than April. This can be attributed to one or all of the following reasons: The $\mathrm{C}_{3}$ grasses and broad leaf species completed their life cycle by June, which resulted in fewer species present for classification. Phenological differences between preflowering and peak flowering may result in spectral differences. The peak flowering may cause changes in internal leaf structure and morphology, resulting in different NIR reflectance. Differences in water content of the leaves between April and June may also affect reflectance spectra. The collection of training samples for the 
background vegetation may also affect classification results between April and June. Regardless of the reasons, our classification results were consistent with the literature. For example, classification accuracies were better for yellow hawkweed and oxeye daisy (Chrysanthhemum leucanthemum) in full bloom than at early and post bloom stages [77]. In addition, high mapping accuracies were achieved for the peak flowering stage of leafy spurge [60], which indicated that image classification at preflowering and post-flowering stages would have missed some areas occupied by this species because of its similar spectral characteristic with background vegetation.

With the history of remote sensing, researchers have sought the optimal strategy to extract as much information as possible from remotely sensed data by using the best possible physiological, compositional and structural distinctions in target species, classification algorithm, data transformation and band selection. The accuracy of a classification task can be improved by focusing on most informative bands or spectral regions. Just a few species-specific spectral bands may be sufficient to detect target species. Since both image classifications in April and June provided sufficient accuracies to be used for management decisions regarding musk thistle treatment, our study provides an application of band selection from a very narrow banded hyperspectral imagery and classification method for discriminating and mapping musk thistle.

It is more beneficial for the resource manager to have information regarding weed infestations as early as possible. The image classification in April was not as accurate as the June classification, but was of sufficient accuracy to make management decisions for treating this weed. Data from this study indicate that classification and mapping of musk thistle on an early spring image (April) before it reaches peak flowering, seed production and dispersal stage is sufficient to implement treatments when control measures are needed for the current growing season. When control measures are not needed or planned for the current growing season, mapping of musk thistle infestation at the flowering stage is the better option for more accurate mapping and planning for future control measures.

\section{Conclusion}

Remote sensing techniques offer important opportunities for detecting plant species and mapping the extent of invasions in a timely and spatial manner, especially when the target species have unique characteristics from the co-occurring vegetation mosaic. This study investigated the use of 1-m spatial resolution hyperspectral imagery and the support vector machine classifier for detecting musk thistle infestation in a rangeland pasture. Given the economic and ecological outcomes of invasion by this weed, our results indicate that hyperspectral imagery may be a useful tool for mapping musk thistle infestation. The accuracy assessment revealed that the overall mapping success were $79 \%$ and $91 \%$ for the classified images at preflowering and peak flowering stages, with the user's and producer's accuracy $>71 \%$ and $>78 \%$, respectively. This indicates that detection of musk thistle during the flowering period is higher than the preflowering stage. Our results have implications for rangeland management and productivity. Maps generated at a 1-m scale provide the spatial extent and dynamics of musk thistle infestation over time. These maps can be used for monitoring, planning and control measures. Such maps have also been shown to provide animal distribution, grazing effects and the effects of natural and anthropogenic disturbances in rangelands. Using maps at a 1-m scale, the reduction in range productivity can be estimated, because a single musk thistle per $1.5-\mathrm{m}^{2}$ decreases pasture yields by $23 \%$ [24]. The use of a 1-m spatial resolution hyperspectral image provided valuable 
estimates of musk thistle infestation. Therefore, we recommended that this methodology and technology should be considered when high scale maps are needed for rangeland research and management. Currently, the cost of hyperspectral imagery over large areas may be economically prohibitive in a commercial operation on native rangeland, but these costs will likely decrease with improvements in technology and may allow hyperspectral detection of weed invasion to become an economically useful tool for rangeland weed management.

\section{Acknowledgements}

We are thankful to Johnny Bible, Robert Villarreal, Joy Newton, Sabina Mirik and Daniel Jiminez for their technical assistance. This study was partially funded by the USDA-ARS Areawide Pest Management Program. Project Number: 500-44-012-00. We also express our thanks to the three anonymous reviewers and editor who made critical suggestions and comments to improve the manuscript.

\section{References}

1. Kok, L.T. Classical biological control of nodding and plumeless thistles. Biol. Control 2001, 21, 206-213.

2. Mirik, M.; Steddom, K.; Michels, G.J., Jr. Estimating biophysical characteristics of musk thistle (Carduus nutans) with three remote sensing instruments. Rangeland Ecol. Manage. 2006, 59, 44-54.

3. Zhang, R.; Heberling, J.M.; Haner, E.; Shea, K. Tolerance of two invasive thistles to repeated disturbance. Ecol. Res. 2011, 26, 575-581.

4. Joshi, C.; de Leeuw, J.; van Duren, I.C. Remote Sensing and GIS Applications for Mapping and Spatial Modeling of Invasive Species. In Proceedings of the XXth ISPRS Congress, Istanbul, Turkey, 12-23 July 2004; pp. 669-677.

5. Mooney, H.A.; Hobbs, R.J. Invasive Species in a Changing World; Island Press: Washington, DC, USA, 2000; p. 457.

6. He, K.S.; Rocchini, D.; Neteler, M.; Nagendra, H. Benefits of hyperspectral remote sensing for tracking plant invasions. Divers. Distrib. 2011, 17, 381-392.

7. Polley, H.W.; Johnson, H.B.; Mayeux, H.S. Leaf physiology, production, water use, and nitrogen dynamics of the grassland invader Acacia smallii at elevated $\mathrm{CO}_{2}$ concentrations. Tree Physiol. 1997, 17, 89-96.

8. Czech, B.; Krausman, P.R. Distribution and causation of species endangerment in the United States. Science 1997, 277, 1116-1117.

9. Rauschert, E.S.J.; Shea, K.; Bjørnstad, O.N. Coexistence patterns of two invasive thistle species, Carduus nutans and C. acanthoides, at three spatial scales. Biol. Invasions 2012, 14, 151-164.

10. Somers, B.; Asner, G.P. Hyperspectral time series analysis of native and invasive species in Hawaiian rainforests. Remote Sens. 2012, 4, 2510-2529.

11. Wilcove, D.S.; Chen, L.Y. Management costs for endangered species. Conserv. Biol. 1998, 12, 1405-1407.

12. Wilcove, D.S.; Rothstein, D.; Dubow, J.; Phillips, A.; Losos, E. Quantifying threats to imperiled species in the United States: Assessing the relative importance of habitat destruction, alien species, pollution, overexploitation, and disease. BioScience 1998, 48, 607-615. 
13. Arnett, A.E.; Louda, S.M. Re-test of Rhinocyllus conicus host specificity, and the prediction of ecological risk in biological control. Biol. Conserv. 2002, 106, 251-257.

14. Frazier, A.E.; Wang, L. Characterizing spatial patterns of invasive species using sub-pixel classifications. Remote Sens. Environ. 2011, 115, 1997-2007.

15. Jones, D.; Pike, S.; Thomas, M.; Murphy, D. Object-based image analysis for detection of Japanese knotweed s.l. taxa (Polygonaceae) in Wales (UK). Remote Sens. 2011, 3, 319-342.

16. Miao, X.; Patil, R.; Heaton, J.S.; Tracy, R.C. Detection and classification of invasive saltcedar through high spatial resolution airborne hyperspectral imagery. Int. J. Remote Sens. 2011, 32, 2131-2150.

17. Milbrath, L.R.; Nechols, J.R. Individual and combined effects of Trichosirocalus horridus and Rhinocyllus conicus (Coleoptera: Curculionidae) on musk thistle. Biol. Control 2004, 30, 418-429.

18. Milbrath, L.R.; Nechols, J.R. Indirect effect of early-season infestations of Trichosirocalus horridus on Rhinocyllus conicus (Coleoptera: Curculionidae). Biol. Control 2004, 30, 95-109.

19. Skarpaas, O.; Silverman, E.J.; Jongejans, E.; Shea, K. Are the best dispersers the best colonizers? Seed mass, dispersal and establishment in Carduus thistles. Evol. Ecol. 2011, 25, 155-169.

20. Wiggins, G.J.; Grant, J.F.; Lambdin, P.L.; Ranney, J.W.; Wilkerson, J.B.; Reed, A.; Follum, R.A. Host utilization of field-caged native and introduced thistle species by Rhinocyllus conicus. Environ. Entomol. 2010, 39, 1858-1865.

21. Wiggins, G.J.; Grant, J.F.; Lambdin, P.L.; Ranney, J.W.; Wilkerson, J.B.; van Manen, F.T. Spatial prediction of habitat overlap of introduced and native thistles to identify potential areas of nontarget activity of biological control agents. Environ. Entomol. 2010, 39, 1866-1877.

22. Zhang, R.; Leshak, A.; Shea, K. Decreased structural defence of an invasive thistle under warming. Plant Biol. 2012, 14, 249-252.

23. Ruggiero, D.C.; Shea, K. Effects of interspecific competition on early life history of the invasive thistles carduus nutans and C. acanthoides. Northeast. Nat. 2011, 18, 197-206.

24. Roduner, M.; Cuperus, G.; Mulder, P.; Stritzke, J.; Payton, M. Successful biological control of the musk thistle in Oklahoma using the musk thistle head weevil and the rosette weevil. Am. Entomol. 2003, 49, 112-120.

25. Andersen, G.L. How to detect desert trees using CORONA images: Discovering historical ecological data. J. Arid Environ. 2006, 65, 491-511.

26. Marsett, R.C.; Qi, J.; Heilman, P.; Biedenbender, S.H.; Watson, M.C.; Amer, S.; Weltz, M.; Goodrich, D.; Marsett, R. Remote sensing for grassland management in the arid southwest. Rangeland Ecol. Manage. 2006, 59, 530-540.

27. Mirik, M.; Ansley, R.J. Comparison of ground-measured and image-classified honey mesquite (Prosopis glandulosa) canopy cover in Texas. Rangeland Ecol. Manage. 2012, 65, 85-95.

28. Asner, G.P.; Jones, M.O.; Martin, R.E.; Knapp, D.E.; Hughes, R.F. Remote sensing of native and invasive species in Hawaiian forests. Remote Sens. Environ. 2008, 112, 1912-1926.

29. Asner, G.P.; Knapp, D.E.; Kennedy-Bowdoin, T.; Jones, M.O.; Martin, R.E.; Boardman, J.; Hughes, R.F. Invasive species detection in Hawaiian rainforests using airborne imaging spectroscopy and LiDAR. Remote Sens. Environ. 2008, 112, 1942-1955. 
30. Ge, S.; Everitt, J.; Carruthers, R.; Gong, P.; Anderson, G. Hyperspectral characteristics of canopy components and structure for phenological assessment of an invasive weed. Environ. Monit. Assess. 2006, 120, 109-126.

31. Huang, C.; Asner, G.P. Applications of remote sensing to alien invasive plant studies. Sensors 2009, 9, 4869-4889.

32. Lass, L.W.; Prather, T.S.; Glenn, N.F.; Weber, K.T.; Mundt, J.T.; Pettingill, J. A review of remote sensing of invasive weeds and example of the early detection of spotted knapweed (Centaurea maculosa) and babysbreath (Gypsophila paniculata) with a hyperspectral sensor. Weed Sci. 2005, $53,242-251$.

33. Narumalani, S.; Mishra, D.R.; Wilson, R.; Reece, P.; Kohler, A. Detecting and mapping four invasive species along the floodplain of North Platte River, Nebraska. Weed Technol. 2009, 23, 99-107.

34. Oldeland, J.; Dorigo, W.; Wesuls, D.; Jürgens, N. Mapping bush encroaching species by seasonal differences in hyperspectral imagery. Remote Sens. 2010, 2, 1416-1438.

35. Olsson, A.D.; van Leeuwen, W.J.D.; Marsh, S.E. Feasibility of invasive grass detection in a desertscrub community using hyperspectral field measurements and Landsat TM imagery. Remote Sens. 2011, 3, 2283-2304.

36. Underwood, E.C.; Ustin, S.L.; Ramirez, C.M. A comparison of spatial and spectral image resolution for mapping invasive plants in coastal California. Environ. Manage. 2007, 39, 63-83.

37. Mansour, K.; Mutanga, O.; Everson, T. Remote sensing based indicators of vegetation species for assessing rangeland degradation: Opportunities and challenges. Afr. J. Agr. Res. 2012, 7, 3261-3270.

38. Mewes, T.; Franke, J.; Menz, G. Spectral requirements on airborne hyperspectral remote sensing data for wheat disease detection. Precision Agric. 2011, 12, 795-812.

39. Mirik, M.; Michels, G.J., Jr.; Mirik, S.K.; Elliott, N.C.; Catana, V. Spectral sensing of aphid (Hemiptera: Aphididae) density using field spectrometry and radiometry. Turk. J. Agr. For. 2006, 30, 421-428.

40. Shippert, P. Why use hyperspectral imagery? Photogramm. Eng. Remmote Sensing 2004, 70, 377-380.

41. Thenkabail, P.S. Hyperspectral Remote Sensing of Vegetation; Taylor and Francis: New York, NY, USA, 2011; p. 781.

42. Thenkabail, P.S.; Enclona, E.A.; Ashton, M.S.; van der Meer, B. Accuracy assessments of hyperspectral waveband performance for vegetation analysis applications. Remote Sens. Environ. 2004, 91, 354-376.

43. Mirik, M.; Norland, J.E.; Crabtree, R.L.; Biondini, M.E. Hyperspectral one-meter-resolution remote sensing in Yellowstone National Park, Wyoming: I. Forage nutritional values. Rangeland Ecol. Manage. 2005, 58, 452-458.

44. Mirik, M.; Norland, J.E.; Crabtree, R.L.; Biondini, M.E. Hyperspectral one-meter-resolution remote sensing in Yellowstone National Park, Wyoming: II. Biomass. Rangeland Ecol. Manage. 2005, 58, 459-465.

45. Kokaly, R.F.; Asner, G.P.; Ollinger, S.V.; Martin, M.E.; Wessman, C.A. Characterizing canopy biochemistry from imaging spectroscopy and its application to ecosystem studies. Remote Sens. Environ. 2009, 113, S78-S91. 
46. Ustin, S.L.; Gitelson, A.A.; Jacquemoud, S.; Schaepman, M.; Asner, G.P.; Gamon, J.A.; Zarco-Tejada, P. Retrieval of foliar information about plant pigment systems from high resolution spectroscopy. Remote Sens. Environ. 2009, 113, S67-S77.

47. Ustin, S.L.; Roberts, D.A.; Gamon, J.A.; Asner, G.P.; Green, R.O. Using imaging spectroscopy to study ecosystem processes and properties. BioScience 2004, 54, 523-534.

48. Lawrence, R.L.; Wood, S.D.; Sheley, R.L. Mapping invasive plants using hyperspectral imagery and Breiman Cutler classifications (Random Forest). Remote Sens. Environ. 2006, 100, 356-362.

49. Mirik, M.; Ansley, R.J. Utility of satellite and aerial images for quantification of canopy cover and infilling rates of the invasive woody species honey mesquite (Prosopis Glandulosa) on rangeland. Remote Sens. 2012, 4, 1947-1962.

50. Ge, S.; Xu, M.; Anderson, G.L.; Carruthers, R.I. Estimating yellow starthistle (Centaurea solstitialis) leaf area index and aboveground biomass with the use of hyperspectral data. Weed Sci. 2007, 55, 671-678.

51. Glenn, N.F.; Mundt, J.T.; Weber, K.T.; Prather, T.S.; Lass, L.W.; Pettingill, J. Hyperspectral data processing for repeat detection of small infestations of leafy spurge. Remote Sens. Environ. 2005, 95, 399-412.

52. Hamada, Y.; Stow, D.A.; Coulter, L.L.; Jafolla, J.C.; Hendricks, L.W. Detecting tamarisk species (Tamarix spp.) in riparian habitats of Southern California using high spatial resolution hyperspectral imagery. Remote Sens. Environ. 2007, 109, 237-248.

53. Lass, L.W.; Thill, D.C.; Shafii, B.; Prather, T.S. Detecting spotted knapweed (Centaurea maculosa) with hyperspectral remote sensing technology. Weed Technol. 2002, 16, 426-432.

54. Miao, X.; Gong, P.; Swope, S.; Pu, R.; Carruthers, R.; Anderson, G.L. Detection of yellow starthistle through band selection and feature extraction from hyperspectral imagery. Photogramm. Eng. Remmote Sensing 2007, 73, 1005-1015.

55. Miao, X.; Gong, P.; Swope, S.; Pu, R.; Carruthers, R.; Anderson, G.L.; Heaton, J.S.; Tracy, C.R. Estimation of yellow starthistle abundance through CASI-2 hyperspectral imagery using linear spectral mixture models. Remote Sens. Environ. 2006, 101, 329-341.

56. Michell, J.J.; Glenn, N.F. Subpixel abundance estimates in mixture-tuned matched filtering classifications of leafy spurge (Euphorbia esula L.). Int. J. Remote Sens. 2009, 30, 6099-6119.

57. Parker Williams, A.; Hunt, E.R., Jr. Estimation of leafy spurge cover from hyperspectral imagery using mixture tuned matched filtering. Remote Sens. Environ. 2002, 82, 446-456.

58. Carter, G.A.; Lucas, K.L.; Blossom, G.A.; Holiday, C.L.L.; Mooneyhan, D.S.; Fastring, D.R.; Holcombe, T.R.; Griffith, J.A. Remote sensing and mapping of tamarisk along the Colorado river, USA: A comparative use of summer-acquired Hyperion, Thematic Mapper and QuickBird data. Remote Sens. 2009, 1, 318-329.

59. Evangelista, P.H.; Stohlgren, T.J.; Morisette, J.T.; Kumar, S. Mapping invasive tamarisk (Tamarix): A comparison of single-scene and time-series analyses of remotely sensed data. Remote Sens. 2009, 1, 519-533.

60. Parker Williams, A.E.; Hunt, E.R., Jr. Accuracy assessment for detection of leafy spurge with hyperspectral imagery. J. Range Manage. 2004, 57, 106-112.

61. Congalton, R.G. A review of assessing the accuracy of classifications of remotely sensed data. Remote Sens. Environ. 1991, 37, 35-46. 
62. Congalton, R.G.; Green, K. Assessing the Accuracy of Remotely Sensed Data: Principles and Practices, 2nd ed.; Lewis Publishers: Boca Raton, FL, USA, 2009; p. 183.

63. Lillesand, T.M.; Kiefer, R.W. Remote Sensing and Image Interpretation; John Wiley \& Sons, Inc.: New York, NY, USA, 1994; p. 750.

64. Stehman, S.V.; Czaplewski, R.L. Design and analysis for thematic map accuracy assessment: Fundamental principles. Remote Sens. Environ. 1998, 64, 331-344.

65. Ke, Y.; Quackenbush, L.J. A review of methods for automatic individual tree-crown detection and delineation from passive remote sensing. Int. J. Remote Sens. 2011, 32, 4725-4747.

66. Janssen, L.L.F.; van der Wel, F.J.M. Accuracy assessment of satellite derived land-cover data: A review. Photogramm. Eng. Remmote Sensing 1994, 60, 419-426.

67. Jensen, J.R. Introductory Digital Image Processing: A Remote Sensing Perspective; Prentice-Hall: Upper Saddle River, NJ, USA, 1996; p. 316.

68. Verbyla, D.L.; Hammond, T.O. Conservative bias in classification accuracy assessment due to pixel-by-pixel comparison of classified images with reference grids. Int. J. Remote Sens. 1995, 16, 581-587.

69. Congalton, R.G.; Mead, R.A. A quantitative method to test for consistency and correctness in photointerpretation. Photogramm. Eng. Remote Sensing 1983, 49, 69-74.

70. Rosenfield, G.H.; Fitzpatrick-Lins, K. A coefficient of agreement as a measure of thematic classification accuracy. Photogramm. Eng. Remmote Sensing 1986, 52, 223-227.

71. Mirik, M.; Jones, D.C.; Price, J.A.; Workneh, F.; Ansley, R.J.; Rush, C.M. Satellite remote sensing of wheat infected by Wheat streak mosaic virus. Plant Dis. 2011, 95, 4-12.

72. Mirik, M.; Ansley, J.R.; Michels, G.J., Jr.; Elliot, C.N. Spectral vegetation indices selected for quantifying Russian wheat aphid (Diuraphis noxia) feeding damage in wheat (Triticum aestivum L.). Precision Agric. 2012, 13, 501-516.

73. Andrew, M.E.; Ustin, S.L. The role of environmental context in mapping invasive plants with hyperspectral image data. Remote Sens. Environ. 2008, 112, 4301-4317.

74. Foody, G.M. Status of land cover classification accuracy assessment. Remote Sens. Environ. 2002, 80, 185-201.

75. Thomlinson, J.R.; Bolstad, P.V.; Cohen, W.B. Coordinating methodologies for scaling landcover classifications from site-specific to global: Steps toward validating global map products. Remote Sens. Environ. 1999, 70, 16-28.

76. Mundt, J.T.; Glenn, N.F.; Weber, K.T.; Prather, T.S.; Lass, L.W.; Pettingill, J. Discrimination of hoary cress and determination of its detection limits via hyperspectral image processing and accuracy assessment techniques. Remote Sens. Environ. 2005, 96, 509-517.

77. Lass, L.W.; Callihan, R.H. The effect of phenological stage on detectability of yellow hawkweed (Hieracium pratense) and oxeye daisy (Chrysanthemum leucanthemum) with remote multispectral digital imagery. Weed Technol. 1997, 11, 248-256.

(C) 2013 by the authors; licensee MDPI, Basel, Switzerland. This article is an open access article distributed under the terms and conditions of the Creative Commons Attribution license (http://creativecommons.org/licenses/by/3.0/). 